\title{
An overview on Ancient Trade Exchanges and Modern Economic Theories: Towards a New Approach?
}

\author{
Stefano Bertoldi* \\ Dipartimento di Scienze Storiche e dei Beni Culturali, Università degli Studi di Siena, Italy
}

Submission: October 03, 2017; Published: November 13, 2017

*Corresponding author: Stefano Bertoldi, Dipartimento di Scienze Storiche e dei Beni Culturali, Università degli Studi di Siena, Via Roma, 56, 53100, Siena, Italy. Email: stefanobertoldi2002@gmail.com

Abstract

This mini-review wants to investigate the possibility of approaching the archaeological data by applying modern economic models. In the case of Tuscany, from the roman imperial age to early middle age, we observe phenomena of the organization of commercial circuits, mainly directed towards large urban markets. In the late antiquity, with the productions of Red Engobe ware, we observe a disposition of industries that can be schematized through modern economic rules. With the VI century, there is a phenomenon of clustering of activities among industries, aimed at breaking down a real free market.

Keywords: Economic theory; Agglomeration of productions; Red engobe ware; Late antique economy; Trust theory; Clustering of activities

\section{Introduction}

The degree of detail achieved by archeology, regarding the knowledge of trade in the imperial age and in the late antiquity, mainly thanks to the amphora and sigillata, has reached a level of absolute statistical reliability. The entire Mediterranean has been subjected to archaeological investigations, with research into cities, villas, rural settlements and farmers. In this panorama, Tuscany, at the center of the Italian peninsula, is certainly one of the areas with greater quantity and quality of data. The study of modern economic phenomena, especially in how they operate in space, has produced a lot of models that have created great debate, especially during the twentieth century. Weber's theory of location of industries [1], the model of Christaller's central places [2], the Losch model [3], the agglomeration models of markets, production and transport, are just a few examples of theories proposed for aproaching the landscape and the modern economy.

In Roman archeology, the most discussed economic theory is the "Bang's bazaar" [4]: the author argues that the system of the Roman market (and in general the ancient structured markets) can not be compared with modern ones, because they are similar to a bazaar. The bazaar is distinguished by the high uncertainty of information and the relative unpredictability of demand and supply.

\section{Discussion}

Although fascinating, Bang's theory does not seem to fit the reality of the archaeological data. In Tuscany, for example, between I and V century AD there are statistical trends in the diffusion of Mediterranean pottery: road infrastructures and, more often, waterways are used to get products from Tyrrhenian ports to the inlands. Each network, besides having a natural and/or artificial road, is always marked by the presence of one or more urban markets. The first case is the Arno Valley, in the north of the region, with the Portus Pisanus as port and the city of Pisa as first place for the sorting of goods. The second case is the Ombrone valley, in the south of the region: the main city (the equivalent of Pisa in the Arno Valley) is Roselle. A little further north, there was a road connecting the towns of Populonia and Siena: this infrastructure was used for trade, even during the Mearly middle ages. The genesis of such paths is, in my opinion, derived from the (unconscious) application of the value theory [5]: in fact, moving beyond the threshold of a certain penetration area would lead to an increase in the cost of transport, making the goods too expensive. In each of these carriers, there was at least one big urban market: the population of cities made possible the existence of commercial flow. 
In the study of landscape, it's crucial to understand the minimum area for the sustainability of a particular human settlement. The macro economy and the globalized Roman system, however, go exactly in the opposite direction to the concept of sustainability: a perennially connected world shows the characters of the unsustainable. Just the greatness of the cities made them not sustainability for their territory; imports were necessary for the supplying. This was the mechanism for creating demand and consequently stimulating the supply.

The production of red engobe ware was developed from the III century $\mathrm{AD}$, but more intensely between the $\mathrm{V}$ and the first half of the VII century, these ceramics were imitations of African red slip ware, a product of great success throughout the Mediterranean [6]. The phenomenon of imitating or otherwise inspiring a particular object of success is widely known in all historical ages.

The appearance of manufacturing centers of this kind of pottery confirms the existence of a free-market circuits during the imperial age: the consumer, who wasn't obliged to choose the product that monopolizes the market, used the "vote with the wallet" weapon to influence industry choices. The principles that move the red engobe ware market are the imitation of a winning idea and the moving of industries close to the big markets.

However, for apply economic models to antique productions and trade flows must presuppose the presence of the free market. The influence of Roman aristocracies on the economy, through their political position, is a complex issue, but some elements show that, at least in some periods, this event has occurred. Some authors see behind the intense development of exports of "sigillata italica" from Arezzo between the end of the I century $\mathrm{BC}$ and early I century $\mathrm{AD}$ the fact that Mecenate was born in the tuscan city [7].

A statistical anomaly can be identified in the third century, when imports from Iberia increase, while African imports are decreasing; the general trend shows that between I and V century, with the exception of III, the iberian products decrease until the disappearance from the Tuscan markets, while the tunisian goods will come to monopolize them. The interpretation of this statistic, which has also been observed in Rome, might be the victory of Septimus Severus. In fact, the emperor proceeded to purge the enemies and to the confiscation of their assets in favor of the imperial private property (res privata). The severian period accelerates imperial control processes on the supply of Rome and the army [8].

During the III century there was an economic crisis, mainly based on inflationary issues of the currency. Growing inflation was blocked by limiting gold and silver extraction: the result was to increase the purchasing power of the rich people, who had the opportunity to tense high-value coins, while the category of small owners became impoverished. Lo Cascio interprets the crisis of the III century through the economic law of Gresham: during the XVI century, the British banker argued that those who control the market have the ability to pick only strong coins with high intrinsic value and pay only with a weak coin whose nominal value is much higher than the real one [9]. For the senatorial class it was extremely easy to influence the political and economic life of the Empire; it is therefore possible that the crisis has been triggered by the rich population.

Despite these examples of attempts to political influence within economic and commercial systems, the complexity, the size and the longevity of the Roman world, guaranteed a substantial dominance of the free market.

The theory of "golden age of farmers"proposed by Wickham, criticized for almost thirty years, creates also today lot of discussion [10]. The author's opinion is that during the VI century, the free farmers were the class who benefited most from the big changes, especially because they no longer had to pay the land tax. Although we can not fully accept this perspective, it is certain that in the 6th century and during the Lombard reign, fiscal pressure decreased, for the disorganisation of the State.

The Tuscan productions between VI and the first half of VIII show the characters of (a) agglomeration of industries in a site or territory, (b) organization of industries close to the markets, (c) organization of industries close to road infrastructure and waterways. The result was to turn companies from competitor to partner.

\section{Conclusion}

The tendency to form large urban areas could be seen as attempting to create enormous (not self-sustainable) markets, the result of a political and economic scheme.

The red engobe ware, at least until the 6th century, does not replace the African red slip ware: it is imitation, of lower quality and cost, for an alternative market segment. We are in the presence of a kind of "Knowledge spillover", which reproduces innovation (or anyway the winning idea) and brings industries closer to consumers to reduce costs.

The Tuscan productions that developed between late antiquity and early middle ages, starting from the red engobe ware, was not chaotic in space and show agglomeration characters: these processes encouraged raw material obtaining, reduce shipping costs to markets, and ultimately had the power to influence demand and prices by increasing or decreasing the supply (Home market effect). The result is a sort of clustering of activities and the emergence of a trust system. With this method, the companies controlled the free market during VI century.

Some examples of agglomeration are the productions of Torraccia di Chiusi, San Genesio and the area of Grosseto: but also the division into sectors of production of Miranduolo could be an indication of the presence of a trust. 
The spatial rules with which Mediterranean goods are spread reveal the full awareness of markets and the economy by producers and traders: the application of value theory in conjunction with red engobe ware, show a small incidence of the Roman bazaar.

Finally, I think that we should approach the regularity of the Roman and Late Antique businesses as complex system characterized by spatial and economic settings. We can not assert the direct application of modern economic theories, but we can approach the archaeological data through some key concepts, such as agglomeration, sustainability, value theory, competition and partnership.

\section{Acknowledgment}

This article is part of the PhD project of the Author. The project was funded by the University of Pisa and the Tuscany Region.

\section{Conflict of Interest}

I declare that there is no economic interest or conflict of interest.

\section{References}

1. Weber A (1929) Theory of the location of industries, Chicago University Press, Chicago, USA.

2. Christaller W (1933) Die zentralen Orte in Suddeutschland, Gustav Fischer, Jena, Germany.

3. Losch A (1940) Die raumliche ordnung der Wirtschaft, Gustav Fischer, Jena, Germany.

4. Bang PF (2008) The Roman Bazaar: a comparative study of trade and markets in a tributary empire, Cambridge University Press, Cambridge, United Kingdom.

5. Smith A (1776) An inquiry into the nature and causes of the wealth of nations. Strahan W and Cadell T, London, United Kingdom.

6. Castiglia G (2014) Il Duomo di Siena. Excavations and pottery below the Siena Cathedral, Archeopress, Oxford, United Kingdom, pp. 78-85.

7. Sangriso $P(1998)$ Terra sigillata e politica augustea: alcune note su Cn. Ateius, Studi Classici e Orientali XVI(3): pp. 919-932.

8. Lo Cascio E (2007) Mercato libero e "commercio amministrato" in età tardoantica. In: Zaccagnini C, Mercanti e politica nel mondo antico, L'Erma di Bretschneider, Roma, Italy, pp. 307-326.

9. Lo Cascio E (2008) La dimensione monetaria e finanziaria della crisi del III secolo d.C., Studi Storici XLIX: pp. 877-894.

10. Wickham C (1988) L'Italia e l'Alto Medioevo, Archeologia Medievale XV: pp. 105-124.

\section{Your next submission with Juniper Publishers} will reach you the below assets

- Quality Editorial service

- Swift Peer Review

- Reprints availability

- E-prints Service

- Manuscript Podcast for convenient understanding

- Global attainment for your research

- Manuscript accessibility in different formats

( Pdf, E-pub, Full Text, Audio)

- Unceasing customer service

Track the below URL for one-step submission https://juniperpublishers.com/online-submission.php 